\title{
On Defining "Imaginary" Beings and Attributes: How Do Lexicographers Cope with Culturally Determined Differences in Beliefs about Cosmology, Ontology and Epistemology?*
}

Piet Swanepoel, Department of Afrikaans and Theory of Literature, University of South Africa, Pretoria, Republic of South Africa (swaneph@unisa.ac.za)

\begin{abstract}
Members of linguistic communities often have opposing beliefs about the existence of beings denoted by lexical items or about the truth of the attributes ascribed to entities. As very little research has been forthcoming in this regard, this article focuses on how people's beliefs about existence and truth are encoded in explanatory dictionaries, and on the kind of semantics that is needed to account for these beliefs. The way in which dictionaries define issues of existence and truth against a default world view is outlined in Section 2. Section 3 indicates what happens if the default world view of lexicographic descriptions changes and how cultural biases operate in the treatment of the meaning of lexical items that denote "imaginary" beings or "imaginary" attributes. Section 4 summarizes the main findings of the article and delimits topics for further research.
\end{abstract}

Keywords: IMAGINARY BEINGS, FABULOUS CREATURES, DEFINING ATTRIBUTES, LEXICOGRAPHIC DEFINITIONS, EXISTENCE, TRUTH, SENSE, REFERENCE, DENOTATION, IDEALIZED COGNITIVE MODELS, COGNITIVE SEMANTICS, CULTURAL BIAS, CULTURAL SENSITIVITY

Opsomming: Oor die definiëring van "denkbeeldige" wesens en eienskappe: Hoe hanteer leksikograwe kultureel bepaalde verskille in beskouings oor die kosmologie, ontologie en epistemologie? Lede van taalgemeenskappe het dikwels opponerende beskouings oor die bestaan van wesens waarna leksikale items verwys of oor die waarheid van die eienskappe wat aan entiteite toegeskryf word. Omdat baie min navorsing in dié verband beskikbaar is, fokus hierdie artikel op hoe mense se beskouings oor die bestaan en waarheid ten opsigte hiervan in verklarende woordeboeke gekodeer word, en op die soort semantiek wat benodig word om hierdie opvattings te verantwoord. Die manier waarop woordeboeke kwessies van bestaan en waarheid teen 'n verstekwêreldbeskouing omskryf, word in Afdeling 2 geskets. Afdeling 3 dui aan wat gebeur indien die verstekwêreldbeskouing van leksikografiese

* This article is an extended version of a paper presented at the Tenth International Conference of the African Association for Lexicography, organised by the Sesiu sa Sesotho Lexicography Unit, University of the Free State, Bloemfontein, Republic of South Africa, 13-15 July 2005. 
omskrywings verander en hoe kulturele vooroordele 'n uitwerking het op die behandeling van die betekenis van leksikale items wat verwys na "denkbeeldige" wesens of "denkbeeldige" eienskappe. Afdeling 4 som die hoofbevindinge van die artikel op en baken onderwerpe vir verdere navorsing af.

Sleutelwoorde: DENKBEELDIGE WESENS, FABELAGTIGE WESENS, DEFINIEEREIENSKAPPE, LEKSIKOGRAFIESE DEFINISIES, BESTAAN, WAARHEID, BETEKENIS, VERWYSINGS, DENOTASIE, GEÏDEALISEERDE KOGNITIEWE MODELLE, KOGNITIEWE SEMANTIEK, KULTURELE VOOROORDEEL, KULTURELE SENSITIWITEIT

\section{Introduction}

Lexicographers faced with the task of compiling a monolingual dictionary of a language will often find that (a) such a language contains lexical items that refer to entities or beings about which the linguistic community may have opposing beliefs as to whether such entities in fact exist, and/or that (b) members of a linguistic community have opposing beliefs as to whether the ascribed attributes of some entities are in fact true.

Typical examples of (a) are lexical items denoting entities which belong to the domain of religion, the spiritual world, or the supernatural. In English, lexical items such as God, god, heaven, hell, angel, spirit, and ghost fall in this category; and in Zulu, lexical items such as tokoloshe, mamlambo, and (i)mpundulu. In the Cambridge International Dictionary of English (CIDE), a class of so-called "imaginary creatures" is distinguished, and the class includes such beings as dragons, unicorns, witches, wizards, fairies, goblins and ghosts, and also the grim reaper. As category they are considered to be figments of human imagination, "not real", because they are created by and only exists in the mind (cf. CIDE, p. 704). As the list indicates, the category includes, besides entities from the domain of religion, also words referring to entities in Greek mythology, fairy tales, and other narratives.

Cases of (b) are illustrated by beliefs such as sangomas possessing the power of divination, the cancer-bush having the property of healing cancer, or lucky charms bringing the wearers luck. In these cases, however, the existence of the entities is not in doubt, but members of the linguistic community may have opposing beliefs as to the truth of the attributes ascribed to these entities.

The importance of these questions of existence and truth for lexicographers lies in the fact that these beliefs often constitute core beliefs and values for a linguistic community, and that irreverence of this fact holds the danger of such a dictionary being rejected by the very community for which it is meant as linguistic tool. For example, Christian and Moslem communities believe in the existence of God, and defining God as an "imaginary being" will no doubt evoke uproar. Likewise, some Zulu speakers believe sangomas to have the power of divination, and either omitting this belief in dictionary definitions or treating it as a possibly false or misguided belief would do injustice to the meaning these 
speakers ascribe to the lexical item and would be found offensive or culturally insensitive.

The question thus arises (a) whether beliefs about the existence of entities and beliefs about the truth of the attributes ascribed to some entities are encoded in dictionaries, (b) if so, what descriptive practices are followed in this regard, and (c) what kind of semantics is needed to provide an adequate account of the beliefs members of a linguistic community have about issues of existence and truth.

As will be indicated below, dictionaries in fact do encode beliefs about the existence of entities and beliefs and about the truth of the attributes of others, although very little research could be found that spells out either what lexicographic principles are followed in this regard or what kind of lexical semantics backs up lexicographic principles and descriptive practices.

The first main goal of this article is therefore to provide such an analysis.

In Section 2, current lexicographic views and practices in a number of modern dictionaries are analysed. It is indicated that ontological and epistemological beliefs are indeed incorporated into lexicographic definitions and that lexicographers have developed a number of descriptive devices to signal differences in the ontological and epistemological beliefs held by a linguistic community. It is argued, furthermore, that in the dictionaries under consideration, lexicographers operate with a default world view (i.e. cosmology) in which the physical world is the main point of reference. All other "possible" worlds are taken as some form of deviance and marked as such. Issues of existence and truth are treated on the basis of possible worlds, allowing the lexicographer - on the face of it - to avoid direct personal commitments as to such ontological and epistemological questions.

In Section 3, it is indicated, first of all, how a change in the default world view (cosmology) of a dictionary or encyclopaedia changes the way lexical items are defined and how ontological and epistemological beliefs are integrated in such a world view and in encyclopaedic entries. Defining practices in the Dutch medieval bestiary Der naturen bloeme ("The most beautiful from nature") are analysed and used as illustration.

Major shifts in world views often take ages, but monolingual dictionaries based on historical principles are often faced with the problem of having to reflect such changes. For example, in the Middle Ages, dragons were believed to exist in the physical world; now they are deemed to be imaginary creatures. To illustrate some of the current approaches to such historical changes in world views, an analysis is provided in Section 3.2 of the way the senses of the lexical item dragon is presented in the OED. The cultural bias that is operative in the treatment of dragon is also illustrated with regard to the way lexical borrowings can be dealt with.

A major problem confronting lexicographers in this regard is finding a semantic theory which could provide a basis for analysing people's beliefs about existence and truth and which could be used for the description of these beliefs in the definitions in an explanatory dictionary. 
In the rest of this article, cognitive semantics will be used for this purpose. The three main constructs which will be analysed are dictionary definitions, lexical meanings, various kinds of Idealized Cognitive Models and the relationships between them:

$$
\text { dictionary definitions — lexical meanings — Idealized Cognitive Models }
$$

In line with cognitive semantics, it will be accepted that lexical meanings are mental constructs consisting of one or more beliefs (including those on existence and truth), and no strict distinction is maintained between so-called linguistic and encyclopaedic beliefs. Furthermore it is accepted that the meaning of lexical items (or its comprising beliefs) relate to, are construed against or motivated by more encompassing mental constructs, often called frames, cultural models or, more generally, Idealized Cognitive Models (ICMs) (cf. Holland and Quinn 1987, Lakoff 1987, Lakoff and Turner 1989, Palmer 1996, Shore 1996 and Taylor 1995 for a detailed discussion). World views are taken to be one class of such an ICM, which functions as justificatory contexts for certain beliefs. For example, a number of religions define a world or cosmos, and thus a reality, that includes not only the physical world but also a spiritual world with places equivalent to the Christian heaven and hell. Holy scriptures and religious dogma, as well as religious metaphysics, are the sources of these realities and they dictate how the real world is to be construed and populated, and how these worlds, their creatures and their logics or laws within such a cosmos interact.

In this regard, domains of religious experience and understanding are world views which are socially acquired and which explicates, according to Goodenough (see Keesing 1974: 77), what has to be known or believed in order to operate in a society. Such a world view furthermore acts as a model of what constitutes reality, as a model for perceiving, relating, and otherwise interpreting material phenomena; it provides standards for deciding what is or what can be, for deciding what to feel about it, what to do about it, and how to go about doing it. Such world views or ICMs thus permeate all our experiences and understanding of the realities with which we interact on a daily basis, and lexical items denote chunks of these experiences and understanding.

As noted by Lyons (1977: 209-211), there are currently no strict rules or preferred approaches of methods as to what dictionary definitions have to encode about lexical meanings as mental constructs. In most cases, dictionary definitions are constructed with pragmatic goals in mind, such as to explain the meaning(s) of lexical items; consequently their success should be judged in terms of these pragmatic goals. The focus in this article, however, will be on how the defining features chosen for lexicographic definitions relate to specific beliefs about the existence of entities and their attributes and the larger encompassing ICMs against which these beliefs are motivated. 
2. Encoding ontological and epistemological beliefs: default and deviance in some modern dictionaries

\subsection{Default presuppositions and justificatory context}

Dictionary definitions by default attempt to describe and explain the meaning(s) people of a linguistic community associate with a lexical item, and they do so by listing a number of such belief-attributes. For example, CIDE, p. 567, defines the primary meaning of the lexical item frog in terms of a belief about the category this entity belongs to and in terms of a number of beliefs about its morphology and habitat:

(1) frog ANIMAL ... a small animal which has a smooth skin, lives in water and on land, has long powerful back legs with which it jumps, from place to place, has no tail, and is usually greenish-brown in colour

The first hypothesis to be ventured is that specific ontological and epistemological presuppositions are associated by dictionary users with such lexicographic descriptions of entities. The first is that the entity denoted by the lexical items described in fact exists, and more specifically that it exists as entity within the physical world as this is perceived by our senses (or extensions thereof such as the microscope or telescope). Lyons (1977: 209) notes in this regard that both reference and denotation with the help of language depend on and presuppose the existence of entities and their attributes to which lexical items refer. This view is termed the axiom of existence, i.e that whatever is denoted by a lexical item must exist, just as whatever is referred to by means of a lexical item must exist.

Secondly, it is postulated that a lexicographic meaning description carries a presupposition of truth with regard to the belief attributes ascribed to this entity, i.e., for example, that it is true that in our physical world a frog belongs to a cognitively salient category (the category SMALL ANIMAL) and that it is true that it has the attributes listed in the definition. To put it simply: We trust that lexicographers will provide us with true information with regard to the beliefs associated with a lexical item. However, the basis for the acceptance of such claims about existence and truth is its verifiability in terms of our sensory experiences of the empirical, physical or natural world, or, as additional justification, the theories and findings of the natural sciences.

The reality against which both the issue of the existence of a frog and the issue of the truth of its attributes are defined, is thus a reality as defined by what we consider to be the empirical, physical or natural world. Lakoff (1987: 158) uses the term basic realism or experiential realism to denote this world view and describes it as, amongst others,

a commitment to the existence of a real world, both external to human beings and including the reality of human experience, 
- a link of some sort between human conceptual systems (the belief system alluded to above - PHS) and other aspects of reality,

- a conception of truth that is not merely based on internal coherence (of some formal system - PHS), and

- a commitment to the existence of stable knowledge of the external world.

By default, lexicographic definitions thus have a logical structure of the following form:

[Ontological Marker [[Truth Marker] Attribute 1, ..., Attribute n]] where

the ontological marker $(\mathrm{OM})$ in this case refers to the external physical or empirical world as perceived by the language user, although not explicitly marked or indicated in the definition itself,

$[A 1, \ldots, A n]$ refers to whatever attributes are presented to describe or explain the conceptualization of the entity to which the lexical item being defined, refers, and

the truth marker (TM), which, although not lexically encoded in the default contexts, reflects the presupposition that the listed attributes are true as commonly believed by members of a linguistic community.

As indicated, $[\mathrm{A} 1, \ldots, \mathrm{An}]$ falls within the scope of the OM and the TM. In general, existence and truth in lexicographic definitions are thus defined relative to some domain of human experience and understanding (and thus meaning). In philosophical terms, the OM may also be interpreted as an indicator of a "possible world", thus indicating that questions of existence and truth are defined, in this default and unmarked case, as the physical world.

\subsection{Deviance and its encoding}

\subsubsection{Encoding existence relative to some domain of experience and under- standing}

Deviance from this default world view and empirical reality as justificatory context is signalled in modern dictionaries by means of a wide range of explicitly encoded ontological and epistemological markers. These are labels and phrases which are presented as parts of definitions and which relativize the question of the existence of entities and the truth of attributes of entities to some possible world or domain of experience and understanding (and thus of meaning) that acts as reference point for issues of existence and truth. In the following examples, these ontological markers are in bold italics. The examples 
are meant to be illustrative and are by no means exhaustive of all possible ways in which the world of reference can be marked.

(2) dragon ... a large fierce imaginary animal, usually presented with wings, a long tail and fire coming out of its mouth (CIDE, p. 418)

(3) God ... (without article) (in Christianity and other monotheistic religions) the creator and ruler of the universe and source of all moral authority; the supreme being (NODE, p. 785)

(4) heaven ... the place where God or the gods are supposed to live; place of complete happiness where the souls of good people go after death (LDOCE, p. 524)

(5) hell ... in some religions, the place where some people are believed to go after death to be punished forever for the bad things they have done during their lives (CIDE, p. 661)

(6) fairy ... a mythical being of folklore and romance usu. having diminutive human form and magic powers and dwelling on earth in close relationship with man (Webster's Third, p. 816)

All of these definitions can be related to the propositional structure (1), where the bold italicized phrases act as ontological markers, indicating the point of reference in terms of which the existence of the entity referred to should be interpreted and the truth of the attributes assigned to them. For example, (6) can be interpreted as: "in the world/domain of myths, folklore and romance, fairies usually have diminutive human form, they have magical powers, and they dwell on earth in close relationship with man". The ontological markers in these examples refer to a wide range of human domains of experience and understanding, but they are explicitly marked to indicate that the default justificatory context is not the physical world, but specific domains of human experience and understanding.

As indicated by Tolkien (n.d), one could use the construct Faërie as OM in example (6), where Faërie then refers to the whole world created in fairy tales, which is one not only populated by fairies, but also by all kinds of creatures and places, activities, processes, etc., and where the laws of the physical world do not apply in toto. Likewise, religions constitute such a world and encode or present a view of the cosmos where not only the physical world exists, but also places such as a heaven and a hell which are populated by various spirits/spiritual beings. As narrative sources such as the Bible, Christian dogma and metaphysics tell us, these exist in reality and have certain properties. In dictionary definitions, an OM such as Faërie/in fairy tales or in some religions thus act, albeit often metonymical, to signal such real worlds or realities.

Although semanticists such as Lakoff (cf. Lakoff 1987) and philosophers such as Niiniluoto (cf. Niiniluoto 1999: 23-25) indicate that these domains of experience have as their source the human imagination, for some people they 
are part and parcel of the reality that exists external to them, and they are made real by various means: by way of symbolization in images and representations which can be empirically cognized and understood, and by the fact that people act on these domains of experience once they have been created, as in religious rituals where spiritual beings are seen as living and acting and to which people pray and bring offerings. Sightings of such beings, or experiences of their presence or attributes are in fact often provided as further (empirical) justification for their existence and for the truthfulness of their attributes (cf. Palmer 1996 and Shore 1996).

Such a view of religion differs markedly from the views on religion and reality in some philosophical schools of thought. According to Niiniluoto (1999), for example, religious beliefs belong to Popper's World 3 of socially and culturally constructed entities. They are seen simply as products of the human imagination, and as such cannot be used as justificatory contexts, given empirical verifiability as criterium for both existence and truth. As Niiniluoto (1999: 233, fn. 6) notes:

Gods do not exist, but were created by men as idealized pictures of themselves. Therefore - excluding descriptive statements about the history, psychology, and sociology of religion - genuine religious judgements about gods and their attributes are not true.

Niiniluoto (1999) argues, however, that for most people their reality is made up of various such domains of experience and understanding, and they may accept and invoke different logics and different justificatory and explanatory contexts for questions as to what exists and what is true, for example, common sense understanding and the natural sciences when it comes to the physical world, but the Bible, religious dogma and metaphysics when it comes to the domain of religion. Such "folk" models of reality therefore of necessity often contain conflicting beliefs (for example Darwinian beliefs about evolution versus creation according to Genesis), but it is an incoherence people accept and live by.

On the face of it, relativization of the questions of existence and truth to some domain of experience and understanding thus opens up the possibility for the lexicographer to "objectively" describe such ontological and epistemological commitments/beliefs of members of a language community. However, given that the empirical world is used as default justificatory and explanatory context of necessity, also encodes a commitment to and prioritization of the physical/empirical world, and thus to a specific world view which is vehemently opposed by anti-realists, anti-objectivists and subjectivists (cf. Niiniluoto 1999). The latter hold (with various nuances of belief) that there is nothing outside of human experience and understanding, i.e. epistemology is prioritized above and precedes ontology, and what is experienced as real, existing and true, first and foremost has its origin in the human mind.

With regard to the issue of existence, there are, however, also some cases 
which are not so clear-cut and different ontological markers could then be used to signal different contexts of justification. In the following example, the ontological marker mythical or actual is used to signal that the mamlambo may in fact be some mythical creature (and exists in some mythical domain of experience) or the lexical item may be used to denote an entity that in fact exists in the physical world:

(7) mamlambo ... A river snake mythical or actual, about which there are varied beliefs (DSAE, p. 211)

\subsubsection{Encoding the relative truth of attributes}

A second set of relevant examples are definitions of entities which are accepted or believed to exist in the real word, but of which there may be differences of opinion as to the truth of the attributes assigned to them. In these definitions, the ontological context is the physical world and the entities are accepted to exist in this world, but truth markers (TMs) are used as part of definitions to indicate that the issue of truth must be relativized to some point of reference. Compare the following examples:

(8) lucky charm she always wears a lucky charm (= one that she thinks will cause good things to happen by chance) (CIDE, p. 846)

(9) sangoma ... An African witchdoctor ..., usu. a woman often claiming supernatural powers of divination (DSAE, p. 306)

(10) (i)mpundulu (bird) ... The lightning bird ... An evil spirit about which there are various beliefs ... It is invoked by witches, and freq. cited before judges as the instigator or cause of crime ... (DSAE, p. 231)

Again, the issue of truth is relativized to some reference point and truth markers are used to indicate which of the beliefs about the attributes of real entities should be read against or are justified in terms of the physical world (the default justificatory context) and which against some other point of reference (the deviant justificatory context). For example, definition (9) makes the statement that a sangoma is usually a woman, but the truth of the attribute of having supernatural powers of divination is relativized to the beliefs and experiences of the sangomas themselves.

One truth marker that is often used, is believed to (be/have). Although the point of reference it denotes is rather vague, it does signal that the truth of what follows in the definition should be relativized to some non-empirical context. This follows mainly because such a truth marker is not used when the justificatory context is the physical world. This becomes evident from the oddity caused by inserting such truth markers in definitions that list attributes which are all accepted as being empirically true (by default). See the following definitions: 
(11) frog a small animal [believed to have] a smooth skin, lives in water and on land, has long powerful back legs with which it jumps, from place to place, has no tail, and is usually greenish-brown in colour

(12) frog ANIMAL ... a small animal which has a smooth skin, lives in water and on land, [and is believed to have] long powerful back legs with which it jumps, from place to place, has no tail, and is greenish-brown in colour

Just as uncertainties may exist with regard to the issue of existence, lexicographers may also be in doubt as to the truth of some beliefs about the attributes of entities, especially when some form of empirical justification could be brought forward to support these beliefs. In the following example, this is indicated by the truth marker has, or is believed to have:

(13) witch ... a woman who has, or is believed to have, magic powers, esp. who can cast spells on people (LDOCE, p. 1264)

\section{Changing the default world view and its lexicographic implications}

World views and folk theories can and do change, as is evidenced by the differences in the dominant world views of the Middle Ages, the period of enlightenment during the Renaissance, and that of "modern man" in the 21st century. Over such extended periods, world views may change dramatically or gradually with regard to their conceptual content. Some beliefs may persist, others may undergo only slight modification. In this section, two sets of data will be considered to have a closer look at how such changing world views effect the design of definitions and the way in which issues of existence and truth are handled in such definitions. The first set of data is taken from the medieval bestiaries, and more specifically the Dutch bestiary Der naturen bloeme of Jacob van Maerlant. The second set of data is taken from modern dictionaries based on historical principles of which it could be accepted that they should link various periods and changing world views in the entries.

\subsection{Der naturen bloeme: a culturally-determined "insider's" perspective}

Jacob van Maerlant completed Der naturen bloeme (DNB) round about 1270. It is a Dutch translation and reworking of Thomas of Cantimpré's encyclopaedia Liber de natura rerum, which itself is a prime example of how knowledge and beliefs about nature were compiled in the Middle Ages from diverse sources in fact, from almost everything that existed and could be attributed to respected authors, past and present. Most of this was done with an explicit didactic aim in mind, viz. to explicate nature for what it could teach us about God and His plan with/for mankind (cf. Nischik 1986: 28-36). 
True to the scholastic tradition, very little was made of empirical verification when it came to issues of existence and truth - these were determined by the existing authoritarian resources/narratives. The result is a portrayal of a world with a clear demarcation of the physical and the spiritual (cf. Lakoff and Turner 1989 for a discussion of the Great Chain of Being underlying the Western Christian world view). However, this physical world was believed to be populated with a host of Plinian monster races, a host of creatures from Greek mythology, and a variety of other fabulous creatures, often accredited with equally fabulous or supernatural attributes (cf. Cohen 1992, Clair 1967 and Friedman 1981). As is exemplified in the cases discussed in Section 2, some of these fabulous attributes were also credited to creatures which in fact exist in the external world, for example the notions that the bear licks its offspring to life after birth and that the pelican feeds its offspring with its own blood.

Despite the curious mixture of fable and fact in the medieval bestiaries, the descriptions of what is now considered to be mythical animals was given with the belief that these animals in fact existed in the natural world; consequently, they were described in DNB within a conceptual framework that can be discerned for the category (EXISTING) ANIMAL underlying all the encyclopaedic entries in DNB (cf. Swanepoel 2004):

\section{CONCEPTUAL FRAME FOR THE CATEGORY ANIMAL}

1. Name (Latin, Dutch equivalents and etymology)

2. Morphological features (esp. outstanding, strange or deviant physical features)

3. Habitat (often linked to the mappa mundi)

4. Behaviour and personality features

5. Food/eating habits

6. Procreation

7. Natural enemies/Danger posed to man

8. Instrumental use for humans

As source of food

Preparation of dishes

As source for medicinal use (linked to the doctrine of the tempers)

How to hunt down the animal

Body parts to be used and preparation of medicinal products

As source for other uses (e.g. clothing)

9. Symbolic-moral values

10. Supplementary information

Sources of information

Reflections on factuality/truth of information

11. Illustrations

Table 1: A conceptual framework for describing animals in Der naturen bloeme

In DBN's description of the dragon, for example, Van Maerlant (cf. Van Maerlant 1989) lists its morphological features, its habitat, the danger it poses to 
man, the elephant as its natural enemy, the medicinal properties of the magic stone it carries in its forehead, ways to catch the dragon, the potions which can be made from the magic stone, and his sources of information.

With regard to the description of animals, Van Maerlant therefore makes no explicit distinction between so-called existing and non-existing animals in $\mathrm{DNB}$, and all of them are viewed, understood and described as a single category, given the belief that all of these animals, including the dragon, inhabited the external world. As such, these encyclopaedic entries present an "insider's" view of what constitutes reality within a specific culture, as backed up by a justificatory context of what the Bible and respected authors have to say about the world, its structure and inhabitants.

\subsection{Dictionaries based on historical principles: an "outsider's" view}

Dictionaries which base the organization of their definitions on historical principles, such as OED, WNT and Webster's Third, typically organise the definitions as these are evidenced from earliest to most recent usages of a lexical item. What is of interest in this regard, therefore, is the way in which lexical items referring to what is now considered to be imaginary beings, such as the dragon, are defined in these dictionaries. More specifically, the question is how lexicographers treat the changing world views or beliefs about the existence of these animals over the span of a specific period.

In analysing the definitions provided for dragon in OED, WNT and Webster's Third, the sources of citations span a period from as early as the 12th century to the 18th century, and two primary senses are discerned for dragon, viz. the obsolete reference to a snake or a serpent and then its meaning as it pertains to what is now considered the mythical animal. The following entries from OED are illustrative of the lexicographic approach taken in these three dictionaries. The issue of the existence of the dragon is seen from a modern perspective in as much as it is labelled a mythical animal (cf. sense 2), irrespective of the fact of the belief in its existence during the Middle Ages (and in some sources even as late as the 17th century; cf. Borges 1987: 154):

(14) dragon ... 1. A huge serpent or snake; a python. Obs. in etymol. use.

2. A mythical monster, represented as a huge and terrible reptile, usually combining ophidian and crocodilian structure, with strong claws, like a beast or bird or bird of prey, and a scaly skin; it is generally represented with wings, and sometimes as breathing out fire. The heraldic dragon combines reptilian and mammalian form with the addition of wings.

It is difficult to separate senses 1 and 2 in early instances. (OED, p. 1012)

The use of the OM mythical therefore clearly indicates that the issue of the existence of the dragon is viewed from the outsider's perspective of the modern 
world view of basic realism. The fact that the use of dragon in at least some of the sources used for citations in the lexicographic articles could have presupposed the existence of the animal in the real world, is not accounted for. A culturally biased perspective on the meaning and understanding of the denotation of dragon is therefore provided with regard to the historical facts.

Borges (1987: 154), in reflecting on this modernist perspective on the dragon within Western cultures, provides the following insightful comment:

People believed in the reality of the Dragon. In the middle of the sixteenth century, the Dragon is recorded in Conrad Gesner's Historia Animalium, a work of a scientific nature.

Time has notably worn away the Dragon's prestige. We believe in the lion as reality and symbol; we believe in the Minotaur as symbol but no longer as reality. The Dragon is perhaps best known but also the least fortunate of fantastic animals. It seems childish to us and usually spoils the stories in which it appears. It is worth remembering, however, that we are dealing with a modern prejudice, due perhaps to a surfeit of Dragons in fairy tales.

\subsection{Cultural bias and lexical borrowings}

This kind of cultural bias or prejudice is, however, not only a feature of the historical treatment of lexical meaning and the related issues of existence and truth. It could, and also does show up, for example, in the way dictionaries define lexical items borrowed from other languages. The following borrowings from Zulu into English and their definitions in the DSAE are illustrative of this phenomenon:

(15) (i)mpundulu (bird) ... The lightning bird ... An evil spirit about which there are various beliefs ... It is invoked by witches, and freq. cited before judges as the instigator or cause of crime ... (DSAE, p. 231)

(16) tokoloshe ... An evil spirit widely believed in by both urban and rural Africans: it is invoked in witchcraft and offered as an extenuating circumstance in criminal cases... Tokoloshe haunted me says the mad Hillbrow killer. I had been attacked by the tokoloshe and I was hopelessly drunk ... The first I knew of what I had done was when the police arrested me at my work on Monday. Post 18.1.70 (DSAE, p. 372)

(17) tokoloshe... (in African folklore) a mischievous and lascivious hairy water spirit (NODE, p. 1949)

What is of interest in these definitions is the choice of defining attributes that was made from all the relevant beliefs people may have of the impundulu bird and the tokoloshe. In both (15) and (16), for example, it is mentioned as defining attribute that Africans frequently offer these two spirits as explanation, excuse or mitigation for some illegal deed before the law. Although merely stated as 
observed fact, and without any moral comment, it reflects the lexicographer's bias as a cultural outsider in as much as it is not linked to or contextualized within the religious model of spiritual possession which is part and parcel of a number of traditional African religions (cf. Boddy 1997). In such religions, loss of personal agency through spiritual possession is seen and experienced as a reality.

This case has an analogue in the efforts of the former South African cricket captain, Hansie Cronjé, to attribute his fixing of cricket matches to the work of the devil, but both cases illustrate the basic conflict between the common sense world views of ordinary people about spiritual possession and agency and the world view of the law in which beliefs about spiritual possession and agency are linked to psychological instability - the reference to the mad killer in the quotation at tokoloshe perhaps being no coincidence.

In definition (17), however, no reference is made to the fact that spiritual possession by the tokoloshe is offered as mitigation for some misdeed, which again raises the question of how lexicographers decide on the defining attributes for their definitions. Such selections for the construction of dictionary definitions are in fact dictated by lexicographers' biases or impressions of the saliency of beliefs.

\section{Conclusion}

Given the lack of research on how beliefs of existence and truth are encoded in dictionaries, this study is only exploratory in nature. The findings do, however, permit a few general conclusions.

An analysis of current descriptive practices in a number of dictionaries in Sections 2 and 3 clearly indicates that lexicographers encode the beliefs people have about the existence of the entities referred to by lexical items and about the truth of the attributes accredited to entities. This is clearly done from a specific cultural perspective, and more specifically in modern explanatory dictionaries, from the perspective of reality construed as existing as an independent external real or empirical world and people's common sense understanding of this world. The latter acts as default reference point with regard to issues of existence and truth; all deviances from this point of reference are therefore explicitly marked with the help of ontological and epistemological/truth markers.

The second major point to be made is that one can in principle not construct an explanatory dictionary and do so in an objective way, i.e. without adhering to a specific world view. The decision on what the default world view should be for any dictionary therefore becomes critical in compiling an explanatory dictionary, and this has to be made by a careful analysis of the cultural model(s) of the linguistic communities whose language will be the object of 
description. Such models may or may not coincide with those of the lexicographer, but obviously those of the linguistic community should have priority. As indicated in the case of Der naturen bloeme, homogeneity with regard to the dominant world view simplifies the lexicographer's task as deviances become unnecessary to mark; heterogeneity, on the other hand, forces one to make an explicit choice for a default world view and deviances have to be marked.

Thirdly, lexicographers should be extremely sensitive to cultural biases in defining lexical items. Careful consideration should be taken as to whose beliefs are encoded in dictionary definitions, especially also in linguistic communities which are culturally very diverse - speakers of (varieties of) English in South Africa, being a prime example.

The analysis and discussion of the encoding of truth and existence in dictionary definitions started off with a rather minimalist set of assumptions about dictionary definitions, lexical meanings as mental constructs, ICMs as broader cognitive constructs against which lexical meanings are defined and motivated and the links that hold between them. It served this exploratory analysis well, but obviously the theoretical framework needs further refinement, especially with regard to the kinds of human domains of experience, understanding and meaning (or ICMs) taken by default or by deviance to act as justificatory contexts and the variety of ways they are encoded in dictionary definitions.

Furthermore, the way in which dictionaries relativize aspects of existence and truth to specific justificatory ICMs, is most probably only a small manifestation of a much wider phenomenon in dictionaries that needs to be researched and explicated. As Niiniluoto (1999: 227-228) indicates, relativism abounds. Concepts of existence and truth are only one of a host of cognitive categories which are relativized to such ICMs:

Cognitive categories taken to be relative in some respect Ontological concepts: Objects, facts, world, reality Semantic concepts: Truth, reference, meaning Epistemological concepts : Perception, belief, justification, knowledge Methodological concepts: Inference, rationality, progress

Moral categories: Customs, values, ethics, law, politics, religion

Cognitive categories to which other categories are taken to be relative Persons

Groups

Cultures

Environments

Languages

Conceptual frameworks

Theories

Paradigms 
Points of view

Forms of life

Gender

Social class

Social practices

Social interests

Values

Obviously, then, this article has only superficially touched on a much larger and complex phenomenon.

\section{Bibliography}

\section{Dictionaries}

CIDE: Proctor, P. (Ed.). 1995. Cambridge International Dictionary of English. Cambridge: Cambridge University Press.

DSAE: Branford, J. 1987. A Dictionary of South African English. (Third edition. Revised and enlarged.) Cape Town: Oxford University Press.

HAT: Schoonees, P.C., C.J. Swanepoel, S.J. du Toit and C.M. Booysen. 1971. Verklarende handwoordeboek van die Afrikaanse taal. Klerksdorp: Voortrekkerpers.

LDOCE: Proctor, P. (Ed.). Longman Dictionary of Contemporary English. Essex: Longman.

NODE: Pearsall, J. (Ed.). 1998. The New Oxford Dictionary of English. Oxford: Oxford University Press.

OED: Simpson, J.A. and E.S.C. Weiner. 1989. The Oxford English Dictionary. (Second edition). Oxford: Clarendon Press.

Webster's Third: Gove, P.B. (Ed.). 1961. Webster's Third New International Dictionary of the English Language. London: G. Bell and Sons.

WNT: Knuttel, J.A.N. 1916. Woordenboek der Nederlandsche Taal. 's-Gravenhage/Leiden: Martinus Nijhoff/A.W. Sijthoff.

\section{Other literature}

Boddy, J. 1997. Spiritual Possession. Middleton, J. (Ed.). 1997. Encyclopedia of Africa South of the Sahara. Volume 3: 156-160. New York: Charles Scribner's Sons

Borges, J.L. 1967. The Book of Imaginary Beings. New York: Random House.

Clair, C. 1967. Unnatural History. An Illustrated Bestiary. New York/Toronto: Abelard-Schumann.

Cohen, J.J. 1992. The Use of Monsters in the Middle Ages. Journal of the Spanish Society of Medieval English Language and Literature 2: 47-69.

Friedman, J.B. 1981. The Monstrous Races in Medieval Art and Thought. Cambridge, Mass.: Harvard University Press.

Holland, D. and N. Quinn (Eds.). 1987. Cultural Models in Language and Thought. Cambridge: Cambridge University Press. 
Keesing, R.M. 1974. Theories of Culture. Annual Review of Anthropology 3: 73-97.

Lakoff, G. 1987. Women, Fire and Dangerous Things. What Categories Reveal about the Mind. Chicago: The University of Chicago Press.

Lakoff, G. and M. Turner. 1989. More than Cool Reason. A Field Guide to Poetic Metaphor. Chicago/London: The University of Chicago Press.

Lyons, J. 1977. Semantics. Volume 1. Cambridge: Cambridge University Press.

Niiniluoto, I. 1999. Critical Scientific Realism. Oxford: Oxford University Press.

Nischik, T-M. 1986. Das volksprachliche Naturbuch im späten Mittelalter; Sachkunde und Dinginterpretation bei Jacob van Maerlant und Konrad von Megenberg. Tübingen: Max Niemeyer Verlag.

Palmer, G.B. 1996. Toward a Theory of Cultural Linguistics. Austin: University of Texas Press.

Shore, B. 1996. Culture in Mind. Cognition, Culture, and the Problem of Meaning. New York/Oxford: Oxford University Press.

Swanepoel, P. 2004. Wonderbaarlike volke en monsterdiere in Der naturen bloeme van Jacob van Maerlant en die kognitiewe verankering van denkbeeldige kategorieë in die Middeleeuse lewens- en wêreldbeskouing. Tydskrif vir Nederlands en Afrikaans 11(2): 162-183.

Taylor, J.R. 1995. Linguistic Categorization. Prototypes in Linguistic Theory. Oxford: Clarendon Press.

Tolkien, J.R.R. n.d. On Fairy Stories [Online]. Available at: <http://arsen-family.us/ 1066/ onfairystories.html [viewed 15 April 2005].

Van Maerlant, J. 1989. Het boek der natuur. Compilation and translation by Peter Burger. Amsterdam: Em. Querido's Uitgeverij. 